\title{
Cervical relaxation for non-surgical uterus access in Santa Inês ewes
}

\author{
[Relaxamento cervical para acesso uterino não cirúrgico em ovelhas Santa Inês] \\ C.R. Leite ${ }^{1}$, J.F. Fonseca ${ }^{2}$, D.A.M. Fernandes ${ }^{1}$, J.M.G. Souza-Fabjan ${ }^{1}$, \\ F.O. Ascoli ${ }^{1}$, F.Z. Brandão ${ }^{1^{*}}$ \\ ${ }^{1}$ Faculdade de Veterinária, Universidade Federal Fluminense - Niterói, RJ \\ ${ }^{2}$ EMBRAPA Caprinos e Ovinos - Coronel Pacheco, MG
}

\begin{abstract}
The present study was composed by two experiments aiming to develop a cervical dilation technique for non-surgical access to Santa Inês ewe's uterus. In Experiment 1, thirty ewes underwent four epidural treatments. The three experimental treatments used $2.0 \mathrm{mg} / \mathrm{kg}$ ketamine. The group receiving this drug alone was denominated $\mathrm{KG}$, whereas other group had ketamine associated with $0.1 \mathrm{mg} / \mathrm{kg}$ morphine (KM) and $\mathrm{KX}$ a third group had ketamine associated with $0.05 \mathrm{mg} / \mathrm{kg}$ xylazine $(\mathrm{KX})$. Control treatment was $1 \mathrm{~mL} / 7.5 \mathrm{~kg}$ saline solution epidurally $(\mathrm{CON})$. Cervical dilation was evaluated in both experiments by attempting to pass a metal rod through the cervix. In Experiment 2, three different hormonal protocols for cervical dilation were tested in thirty ewes. Epidural anesthesia with $2.0 \mathrm{mg} / \mathrm{kg}$ ketamine was the control treatment $(\mathrm{KG})$ and was combined with hormonal treatments: Misoprostol (MI); Oxytocin + Estradiol $(\mathrm{OE})$; Misoprostol + Oxytocin + Estradiol (MOE). In Experiment 1 transposition rate was not different among groups. In Experiment 2, OE presented the highest rate (90\%) while MOE presented 86.2\%, MI $68.9 \%$ and $\mathrm{CON} 62.1 \%$. The study developed a pharmacological protocol that increased cervical transposition making the non-surgical access to the uterus feasible in Santa Inês ewes.
\end{abstract}

Keywords: epidural ketamine, estradiol, misoprostol, oxytocin, sheep cervix

\section{RESUMO}

O presente estudo teve como objetivo desenvolver uma técnica para acesso não cirúrgico ao útero de ovelhas Santa Inês e foi realizado em duas etapas. No experimento 1, 30 ovelhas foram submetidas a quatro tratamentos epidurais. Os três tratamentos teste usaram 2,0mg/kg de cetamina. O grupo que recebeu apenas cetamina foi denominado $K G$, enquanto no segundo grupo a cetamina foi combinada com morfina $(0,1 \mathrm{mg} / \mathrm{kg}-\mathrm{KM})$ e um terceiro grupo recebeu cetamina associada com xilazina $0,05 \mathrm{mg} / \mathrm{kg}-$ $\mathrm{KX}$ ). No grupo controle (CON), usou-se solução salina (1mL/7,5kg de peso). A dilatação cervical foi avaliada em ambos os experimentos pela tentativa de transposição cervical com uma haste metálica. No experimento 2, três protocolos hormonais de dilatação cervical foram testados em 30 ovelhas. Anestesia epidural com 2,0mg/kg de cetamina foi o tratamento controle (CON), combinada com tratamentos hormonais nos grupos: misoprostol (MI); ocitocina + estradiol (OE); misoprostol + ocitocina + estradiol (MOE). No experimento 1, a taxa de transposição não variou entre os grupos. No experimento 2, OE teve a maior taxa (90\%), enquanto MOE apresentou 86,2\%, $\mathrm{MI}_{i} 68,9 \%$ e CON 62,1\%. O estudo desenvolveu um protocolo farmacológico que aumentou a taxa de transposição cervical, tornando o acesso uterino não cirúrgico viável em ovelhas Santa Inês.

Palavras-chave: cetamina epidural, estradiol, misoprostol, ocitocina, cérvix ovina

Recebido em 2 de dezembro de 2016

Aceito em 14 de junho de 2018

*Autor para correspondência (corresponding author)

E-mail: fzbrandao@id.uff.br 


\section{INTRODUCTION}

Embryo collection and transfer in sheep has restricted use because they are mostly performed surgically. The laparotomy and laparoscopy are costly due to the expensive equipment, trained personnel and general anesthesia required. Furthermore, the manipulation of the abdominal cavity may promote adhesions, which reduces the reproductive life of the donor (Revised by Fonseca et al., 2011).

The alternative non-surgical technique is limited due to the ovine cervix, an anatomical barrier to penetration that generally prevents the passage of the catheter through the uterus body (Kershaw et al., 2005). Some studies have already been published focusing on cervix transposition in sheep, reporting the use of modified catheters (Álvarez et al., 2012), hormonal techniques (Gusmão et al., 2009; Candappa and Bartlewski, 2014) and anesthetic protocols (DeRossi et al., 2009), but until now, none were able to be reproduced on a large scale. Moreover, it is known that the success of cervical transposition seems to depend on the breed, and few reports have been published in Santa Inês ewes (Gusmão et al., 2007; Santos et al., 2009), an adapted native breed important for sheep production in tropical regions.

Epidural is a commonly used technique for procedures that require relaxation and analgesia of pelvic limbs, tail, vulva and vagina (DeRossi et al., 2012). Several drugs may be used with this purpose, such as local anesthetics, opioids, alpha-2 agonists and dissociative agents. When used epidurally, these drugs promote analgesia and relaxation with a minimum of undesirable effects, since it is possible to lower the doses and the systemic effects only appear after absorption to the bloodstream (Leme et al., 2008). Analgesia is an important aspect of cervical manipulations since pinching and pulling de cervix are painful stimuli.

Non-pregnant animals show a natural degree of cervical dilation during the follicular phase of the estrus cycle (Kershaw-Young et al., 2009). Studies propose that a sequence of events trigger this relaxation, starting with the follicular development induced by FSH which stimulates a periovolatory increase of $17-\beta$-estradiol and consequently a higher expression of oxytocin receptors (Falchi and Scaramuzzi, 2015). Some studies with oxytocin and estradiol increased cervical transposition rate in ewes (WulsterRadcliffe, et al., 1999; Masoudi et al., 2012). Prostaglandines also have a major role in cervical dilation by smoothening the collagen cervical matrix (Greer et al., 1992). Misoprostol is an analogue of prostaglandine E1 that has been used in some studies to dilate sheep cervix (Gusmão et al., 2009; DeRossi et al., 2009).

The aim of this study was to test pharmacological treatments to promote cervical dilation, analgesia, and relaxation of perineal region, allowing non-surgical access to ewes' uteri, therefore proposing means for the cheap and widespread use of reproduction biotechnologies respecting welfare guides.

\section{MATERIALS AND METHODS}

This study was approved by the Ethics Committee for Research Involving Animals Universidade Federal Fluminense (UFF), protocol $n^{\circ} 191$. The experiment was conducted in the Unidade de Pesquisa em Caprinos e Ovinos located at the farm of UFF, in Cachoeiras de Macacu, Rio de Janeiro, Brazil. The study was carried out in two experiments:

Experiment 1

Thirty cyclic multiparous Santa Inês breed ewes ageing 2 to 4 years old with mean body weight (BW) of $50.7 \pm 5.4 \mathrm{~kg}$ and body condition score (BCS) from 2.75 to 3.5 (in a 1 to 5 scale where 1 represents a cachetic animal and 5 an obese animal) were used. Animals were selected after clinical and ultrasonographic exam that showed general and gynecological health and presenting a corpus luteum at the gynecological evaluation moment. Ewes received two doses of $37.5 \mu \mathrm{g} \mathrm{d}-$ cloprostenol (Prolise ${ }^{\circledR}$, Tecnopec, São Paulo, Brazil) intramuscularly (i.m.), with an 11-day interval. The subsequent procedures were carried out on the seventh day after the second dose of dcloprostenol so that the animals were in the progesteronic phase of the estrus cycle, when embryo recovery and transfer are performed. The females were deprived of food and water for $24 \mathrm{~h}$ and $12 \mathrm{~h}$, respectively. After the lumbosacral region was shaved, ewes were sedated with acepromazine $\left(0.1 \mathrm{mg} / \mathrm{kg} \quad\right.$ Acepran $^{\circledR}$, Vetnil, Louveira, Brazil) and diazepam $(0.2 \mathrm{mg} / \mathrm{kg}$ 
Diazepam, Teuto, Anápolis, Brazil) intravenously (i.v.). Ten minutes after sedation, ewes were placed in sphinxpositionon a table and received aseptic preparation in the lumbosacral region with chlorhexidine (Rioquímica, Barueri, Brazil). A subcutaneous injection of $2 \mathrm{~mL}$ of lidocaine hydrochloride $\left(\right.$ Lidovet $^{\circledR} 2 \%$, Bravet, Rio de Janeiro, Brazil) to desensitize the skin was applied. A 18-gauge Tuohy needle was introduced at a 90 angle to the skin and directed into the epidural space, between the last lumbar and first sacral vertebrae. The correct placement of the needle was confirmed through the hanging-drop technique and loss of resistance to injection (Freitas et al., 2011). The injections were performed within 60 seconds.

The experimental groups were: KG (ketamine $2.0 \mathrm{mg} / \mathrm{kg}$, Ketamina Agener ${ }^{\circledR}$ Agener União Saúde Animal - União Química Farmacêutica Nacional, São Paulo, Brazil), KM (ketamine $2.0 \mathrm{mg} / \mathrm{kg}+$ morphine $0.1 \mathrm{mg} / \mathrm{kg}-$ Dimorf $^{\circledR}$, Cristália Produtos Químicos Farmacêuticos LTDA., Itapira, Brazil) KX (ketamine $2.0 \mathrm{mg} / \mathrm{kg}$ + xylazine $0.05 \mathrm{mg} / \mathrm{kg}$ - Calmium $^{\circledR}$, Agener União Saúde Animal) and control without epidural anesthesics (CON - saline solution, in the final volume of $1 \mathrm{~mL}$ per $7.5 \mathrm{~kg}$ of $\mathrm{BW}$, as the control group). The final volume was fixed to all groups, according to the formula used in $\mathrm{CON}$, and was completed with saline solution. All animals underwent the four treatments with a two-week interval between each treatment. This procedure reduced individual effects to interfere in the results.

After the epidural injection, the animals were placed in sternal recumbency, with the abdomen supported by a semi-circular stool that kept them restrained in an ideal position for cervical access. The technician was unaware of the treatment each animal received. The rectum was emptied and a 2-3 Collin speculum was lubricated and inserted into vulva to explore vagina and cervix of each ewe. With the aid of a light source, external os was located, pinched and pulled back with a modified Allis tweezer. Cervix was fixed outside vulvar commissure with two $26 \mathrm{~cm}$ Pozzi tweezers laterally to cervical opening (Fonseca $e t$ al., 2011). At this time, anal, vulvar and vaginal relaxation were evaluated according a scale from 1 to 4 described by DeRossi et al. (2009).
Cervical transposition attempts were performed with Hegar uterine dilators three times and each trial lasted a maximum of 5min, starting at 10, 20 and 40min after epidural. In case of successful total transposition, a catheter was inserted into the uterus with the aid of a mandrel. The confirmation that the catheter was in the uterine lumen was obtained by the injection and recovery of $20 \mathrm{~mL}$ of saline solution. If the passage was achieved in the first or second attempt, additional attempts were not performed.

The animals had their sedation, motor and sensory response degrees assessed. These parameters were evaluated with grades from 1 to 4, according to the scale described by DeRossi et al. (2005). For sensory response evaluation, animals underwent skin clamping with a hemostat forceps at several points, from the interdigital space of pelvic members to the flank. The evaluations were conducted before sedation (baseline, TB), 10min after sedation (TS) and at 5, 15, 30, 45, 60, 75, 90, 105 and 120min after the epidural injection. Furthermore, the period of time that the animal remained recumbent was measured. Anal sphincter relaxation, vulva and vagina relaxation, analgesia and cervical dilation were measured. Anal sphincter relaxation was evaluated by digital palpation, vulva and vagina relaxation was assessed when the Collins speculum ( 2 or 3 ) was introduced into the vulva. Analgesia was assessed by taking into account the animal reactions to the cervical clamping and traction and the manipulation with Hegar dilators. Cervical dilation was measured during the cervical transposition attempts. Each parameter was evaluated on a 1 to 4 scale as described by DeRossi et al., 2009. The cervical transposition was recorded as a yes or no response.

Experiment 2

Thirty cyclic multiparous Santa Inês breed ewes ageing 2 to 4 years old with mean body weight of $39.6 \pm 5.7 \mathrm{~kg}$ and BCS from 2.75 to 3.5 were selected and used. Ewes received progesterone releasing devices containing $0.3 \mathrm{~g}$ progesterone (Eazi-Breed CIDR ${ }^{\circledR}$, Pfizer, São Paulo, Brazil) for six days, and, $24 \mathrm{~h}$ before the removal of the device, $37.5 \mu \mathrm{g}$ d-cloprostenol (Prolise $^{\circledR}$ ) and 200IU eCG (Novormon $^{\circledR}$, Coopers, Cotia, São Paulo, Brazil) were administered i.m. for estrus synchronization. The subsequent procedures were carried out at the seventh day after device 
removal. Each animal received one more dose of d-cloprostenol $12 \mathrm{~h}$ before the procedures. The preparation of the animals was strictly the same as in Experiment 1.

All ewes received epidural anesthesia with ketamine $(2.0 \mathrm{mg} / \mathrm{kg})$ in the final volume of $1 \mathrm{~mL}$ per $7.5 \mathrm{~kg}$ of BW, completed with saline solution and. The experimental treatments groups were: misoprostol (MI); oxytocin and estradiol (OE); and misoprostol, oxytocin and estradiol MOE, besides the control group $(\mathrm{CON})$, which received only the epidural anesthesia. For the animals receiving intravaginal misoprostol (Prostokos ${ }^{\circledR}$, Laboratório Hebron, Caruaru, Brazil), 200 $\mu \mathrm{g}$ were diluted into $1.5 \mathrm{~mL}$ of saline solution. A 2-3 Collin speculum was lubricated and inserted to explore vagina and cervix of the ewes, and the solution was deposited directly on cervical os. Misoprostol was applied 5hours before the start of cervical transposition attempts with Hegar uterine dilators. For the groups receiving estradiol and oxytocin, a dose of $100 \mu \mathrm{g}$ estradiol benzoate (RIC-BE ${ }^{\circledR}$ Tecnopec, São Paulo, Brazil diluted with $2.5 \mathrm{~mL}$ of saline solution and $2.5 \mathrm{~mL}$ of ethanol was administered i.v. 12 hours before the cervical transposition attempts (Masoudi et al., 2012). Lastly, a dose of 100IU oxytocin (Ocitocina Forte $\mathrm{UCB}^{\circledR}$, Centrovet, Goiânia, Brazil - Masoudi et al., 2012) was administered i.v. $15 \mathrm{~min}$ before the procedure. All groups received $37.5 \mu \mathrm{g}$ d-cloprostenol (Prolise ${ }^{\circledR}$ ) i.m. 12 hours before the cervical transposition attempts. All animals underwent every treatment with a two-week interval, therefore avoiding individual effects to interfere in the results.

Cervical transposition attempts were performed using the same methodology as in experiment 1 . In this experiment, anal sphincter, vulva and vagina relaxation, cervical dilation, analgesia, and transposition rate were assessed using strictly the same method as in experiment 1 . Besides these parameters, order of passage (if transposition was possible during the first, second, third or fourth time the ewe was used, disregarding the treatment) and time of passage (first, second or third attempt) were also registered.
Parametric variables expressed as mean \pm S.E.M. were submitted to one-way analysis of variance (ANOVA) and compared by $t$ test. Nonparametric data were subjected to the Friedman test and cervical transposition rate was compared by Fisher's test. A value of $\mathrm{P}<0.05$ was considered to be statistically significant. Statistical analyses were performed using SAS (Statistical..., 2012) software.

The parameters sedation, motor and sensory responses were compared between groups and evaluation times. Additionally, any interaction between groups and times were considered. The other parameters such as analgesia, cervical dilation, relaxation of anal sphincter, vulva and vagina were evaluated at a single time, and therefore only compared between groups.

\section{RESULTS}

In experiment 1, regardless to the time of evaluation, KX-treated ewes presented the highest $(\mathrm{P}<0.05)$ overall score of sedation $(2.1 \pm 1.1)$, whereas ewes from KM $(1.7 \pm 0.9), \mathrm{KG}$ $(1.6 \pm 0.9)$ and $\mathrm{CON} \quad(1.4 \pm 0.7)$ groups demonstrated sedation to a similar degree. All groups had higher sedation scores $(\mathrm{P}<0.05)$ compared to TB from T05 to T60. Considering the interaction between times and groups, KXtreated ewes presented the highest scores between $\mathrm{T} 15$ and $\mathrm{T} 75$, and both $\mathrm{KG}$ and $\mathrm{KM}$ treatments were similar between each other and to the control $(\mathrm{CON})$ differing from baseline from T05 to T45 (Figure 1).

Regardless to the time of evaluation, KX-treated ewes presented the highest $(\mathrm{P}<0.05)$ overall sensory response scores $(2.4 \pm 1.2)$, whereas $\mathrm{KG}$ and KM-treated ewes (both 1.7 \pm 0.9 ), demonstrated higher scores than the control-ewes (CON: 1.2 \pm 0.5$)$. All groups had higher sensory scores $(\mathrm{P}<0.05)$ compared to TB from T05 to T75. Considering the interaction between evaluation times and groups, the sensory response scores of the control $(\mathrm{CON})$ ewes were lower than all the other groups from T05 to T60, and, after T75, KX-treated ewes presented higher scores than the other groups. Both $\mathrm{KG}$ and $\mathrm{KM}$ treatments were similar between each other and to the control (CON) (Figure 1). 


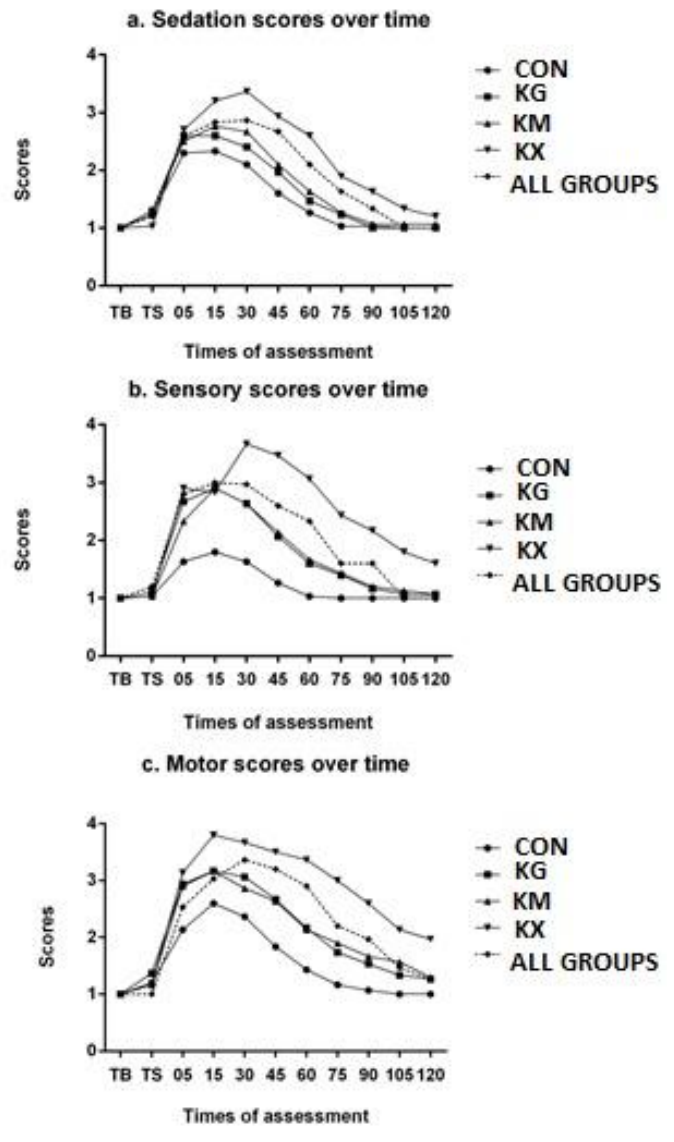

Figure 1. Sedation (a), sensory (b) and motor (c) scores of ewes treated with acepromazine and diazepam, and subjected to epidural injection with saline (CON, control), ketamine (KG), ketamine with morphine (KM), or ketamine with xylazine (KX) over time, at TB (before sedation), TS (10min after sedation) and 5, 15, $30,45,60,75,90,105$ and $120 \mathrm{~min}$ after epidural.

Regardless to the time of evaluation, $\mathrm{KX}$-treated ewes presented the highest $(\mathrm{P}<0.05)$ overall motor response scores $(2.7 \pm 1.2)$, whereas $\mathrm{KG}$

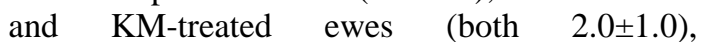
demonstrated higher response than the controlewes (CON: 1.5 \pm 0.8$)$. All groups showed higher motor scores $(\mathrm{P}<0.05)$ compared to $\mathrm{TB}$ from T05 to T75. Considering the interaction between times and groups, the motor response scores of control (CON) ewes were lower than all the other groups from T05 to T60. From T15 to T60, KG and $\mathrm{KM}$ treatments were similar between each other and different $(\mathrm{P}<0.05)$ from $\mathrm{KX}$, which demonstrated higher scores up to the last evaluation at 120min (Figure 1).

The time of recumbency varied among the groups and the KX group showed the longest time (140.4 \pm 2.9 minutes) which was different $(\mathrm{P}<0.05)$ from KM $(90.3 \pm 39.3$ minutes $)$ and $\mathrm{KG}$ (85.7 \pm 27.6 minutes). All groups differed $(\mathrm{P}<$ $0.05)$ from $\mathrm{CON}(53.1 \pm 28.4)$.

The results of anal sphincter, vulva, and vagina relaxation; analgesia; and cervical dilation, are presented in Table 1. Cervical transposition rate was not different among the groups and percentages of successful transpositions showed by the different treatments were: $50 \%$ in $\mathrm{CON}$, $53 \%$ both in $\mathrm{KG}$ and $\mathrm{KX}$ and $47 \%$ in $\mathrm{KM}$.

There were no differences $(\mathrm{P}>0.05)$ among groups in scores of relaxation of the anal sphincter, relaxation of the vulva and vagina, analgesia or cervical dilation. Cervical transposition rate was different among groups $(\mathrm{P}<0.05)$. Results are presented on Table 2.

Regarding the order of passage, the first time the animal was used (61\% of success) differed from the third $(86.2 \%)$ and the fourth $(82.8 \%)$ time the ewe was used. The second $(68.9 \%)$ time was not different $(\mathrm{P}>0,05)$ from any other.

Table 1. Scores of relaxation of anus, vulva and vagina, analgesia and cervical dilation in ewes sedated with acepromazine and diazepam and subjected to epidural injection with saline (CON, control), ketamine $(\mathrm{KG})$, ketamine with morphine (KM), or ketamine with xylazine (KX)

\begin{tabular}{ccccc}
\hline & Relaxation of anus & $\begin{array}{c}\text { Relaxation of vulva } \\
\text { and vagina }\end{array}$ & Analgesia & Cervical dilation \\
\hline $\mathrm{CON}$ & $2.8 \pm 0.9^{\mathrm{b}}$ & $3.0 \pm 1.0$ & $2.6 \pm 0.7^{\mathrm{b}}$ & $2.5 \pm 0.9$ \\
$\mathrm{KG}$ & $3.4 \pm 0.6^{\mathrm{a}}$ & $3.4 \pm 0.8$ & $3.1 \pm 0.7^{\mathrm{a}}$ & $2.6 \pm 0.8$ \\
$\mathrm{KM}$ & $3.4 \pm 0.6^{\mathrm{a}}$ & $3.5 \pm 0.7$ & $3.4 \pm 0.6^{\mathrm{a}}$ & $2.6 \pm 0.9$ \\
$\mathrm{KX}$ & $3.4 \pm 0.7^{\mathrm{a}}$ & $3.5 \pm 0.7$ & $3.6 \pm 0.7^{\mathrm{a}}$ & $2.7 \pm 0.8$ \\
\hline
\end{tabular}

${ }^{a, b}$ Different letters indicate differences within columns (P< 0.05). Scores from 1 to 4, according to De Rossi, (2009). 
Table 2. Cervical transposition rate in ewes subjected to epidural injection with ketamine $(\mathrm{CON})$, or epidural ketamine combined with cervical misoprostol (MI), or i.v. oxytocin plus estradiol (OE) or cervical misoprostol with i.v. oxytocin and estradiol (MOE)

\begin{tabular}{cc}
\hline Group & Transposition rate \\
\hline CON & $60 \%(18 / 30)^{\mathrm{c}}$ \\
MI & $66.7 \%(20 / 30)^{\mathrm{bc}}$ \\
OE & $90 \%(27 / 30)^{\mathrm{a}}$ \\
MOE & $83.3 \%(25 / 30)^{\mathrm{ab}}$ \\
\hline $\mathrm{P}, \mathrm{P}<0.05)$.
\end{tabular}

Considering only the ewes in which cervical transposition was successful, the time taken to achieve it was different $(\mathrm{P}<0.05)$ among groups. Control group had majority of successful transpositions (10/19 - 52,6\%) 20 minutes after epidural injection while groups receiving hormonal treatments had most of its successful transpositions at the first attempt, 10 minutes after epidural injections (MI 13/20 - 65\%; MOE $12 / 24-50 \%$ and OE 18/26 - 69.2\%).

\section{DISCUSSION}

The main objectives of the present study were to compare the efficiency of different pharmacological treatments administered epidurally and to associate the epidural technique with different hormonal treatments to promote cervical dilation in ewes. Two main conclusions can be drawn from this study. First, all groups receiving epidural analgesics showed satisfactory scores of analgesia and relaxation although the epidural alone was not able to dilate the cervix. Second, the association of epidural analgesic with PGF, oxytocin and estradiol succeeded in dilating the cervix with adequate comfort to the animals.

All ewes receiving epidural analgesics showed satisfactory scores of analgesia (3.4), and the three treated-groups had higher scores than the control group (2.6). As expected, the $\mathrm{KX}$ treatment promoted the highest score (3.6), as the xylazine potentiates the analgesic effects of ketamine and reduces the latency period. DeRossi et al. (2009) evaluated the use of spinal $1.5 \mathrm{mg} / \mathrm{kg}$ ketamine in Santa Inês ewes and reported this treatment promoted maximum scores (4.0) of analgesia in some animals, agreeing with our findings. KM treatment probably was not able to produce highest scores of analgesia than $\mathrm{KX}$ when the cervix was pinched and pulled due to its latency period of approximately 30 minutes (DeRossi et al., 2012). The vulva and vaginal relaxation scores were similar in all treated-groups (3.5), and even the control group presented reasonable high score (3.0). This result is probably due to the muscle relaxant effect of the sedatives used, acepromazine and diazepam (Galatos, 2011). Anal sphincter relaxation was more intense in $\mathrm{KG}, \mathrm{KM}$ and $\mathrm{KX}$ (3.4) groups, higher than the control (2.8), reflecting the local anesthetic-like effect of ketamine, blocking $\mathrm{Na}^{+}$channels (Duque et al., 2004).

No significant differences on cervical dilation scores or on the cervical transposition rate were obtained among groups in experiment 1 , suggesting that the cervical canal relaxation is more related to the intrinsic changes of the cervical extracellular matrix than to the relaxation of its smooth muscle. The epidural drugs relax smooth muscle, which is present in small amounts in the sheep cervix, particularly in uterine region (Kershaw et al., 2007), but does not affect the collagen matrix, the most abundant substance in this organ. A previous report demonstrated that the use of ketamine by the spinal route in crossbred sheep allowed the catheter passage in all six ewes. However, there was no control treatment to assess whether the cervix of these animals would have an anatomical advantage or if ketamine was solely responsible for the results (DeRossi et al., 2009), since breed and individual anatomy certainly affects this parameter. In our study, approximately $50 \%$ of the animals receiving control treatment allowed the catheter passage, indicating that the individual anatomical feature has great influence in the cervical transposition.

A significant longest recumbency time was observed in KX-treated ewes (140min), probably due to the deeper level of sedation (supra spinal effects of xylazine) associated with the prolonged blockade in motor system. Obviously, this long time was not a desirable effect, since the whole experimental procedure lasted about 60 min. Considering this undesirable side effect of $\mathrm{KX}$ and the lack of difference in analgesia and relaxation scores from $\mathrm{KG}$ to $\mathrm{KM}$ the use of ketamine alone was considered more suitable for the procedure and chosen for experiment 2 . 
KX-treated ewes presented the highest degree of sedation, which shows that the systemic absorption of this drug potentiated the effect of the sedatives administered intravenously. Ruminants are especially susceptible to alpha 2 agonists due to the distribution of the specific alpha2 adrenoceptor subtypes, compared with other species (Shah et al., 2014). Over time, regardless to the treatment, the sedation scores were different between TB and TS, and similar from T05 to T60, which corresponds to the peak in the action of diazepam and acepromazine association (Araújo et al., 2014).

Regarding the sensory response, the fact that KX-treated ewes presented the highest sensory scores, whereas the $\mathrm{KG}$ and KM-treated ewes demonstrated higher scores than the controlewes, corroborates with the theory that the shortest latency period and the enhancement of analgesia provided by xylazine allowed this group to have the highest scores. The motor response scores followed the same trend of the sensitive response.

The lack of difference among groups in relaxation and analgesia scores in experiment 2 were not unexpected effects confirming that the hormonal treatments used had no influence on these parameters.

The absence of difference in cervical dilation degree among groups in experiment 2, despite the transposition rate difference was not an expected result. This may be explained by the fact that all animals in which the transposition was not feasible, received score 2, meaning that the first rings were transposed, and most of the animals where transposition was possible received score 3. Score 1 - impossibility of transposing any of the rings - was not attributed to any animal and score $4-$ major facility in transposition - was rare. Proximity of scores attributed with major frequency explains the lack of statistic difference.

Both the cervical smooth muscle and extracellular matrix played important roles in cervix relaxation. Analyzing our study results, it becomes clear that oxytocin and estradiol were the hormones responsible for promoting cervical dilation since the use of epidural drugs alone to promote smooth muscle relaxation was not enough to dilate de cervical canal and
Misoprostol alone had a much lower transposition rate, not different from the control group.

Group OE presented the highest cervical penetration rate and this protocol was previously described with success in other studies aiming for oocyte recovery (Flohr et al., 1999) or embryo transfer (Wulster-Radcliffe et al., 1999) in sheep. Flohr et al. (1999) used the same doses, times of drugs administration and routes used in our study. In the Wulster-Radcliffe et al. (1999) study, on the other hand, the only difference was the oxytocin dose (400UI).

A series of combinations of misoprostol and FSH was compared in Welsh Mountain and Île-deFrance sheep (Falchi et al., 2012) regarding the depth of cervical penetration. None of the studied protocols in that study enhanced cervical penetrability, but the experiment design was not cross-over, as the animals were randomly allocated in each group without individual effect control thus. Besides that, all hormones were administered intracervically while, in our study, oxytocin and estradiol were administered i.v.. Also, the times of drug administration and transposition attempts were different.

Gusmão et al. (2009), studying Dorper breed ewes accomplished $95 \%$ of transposition rate using cervical misoprostol. In another study also using misoprostol in Santa Ines ewes (Gusmão et al., 2007), the authors had only $63 \%$ successful cervical transposition for embryo collection. Although using 49 animals the study design was not cross over and the animals were randomly assigned to the 3 groups: control $(\mathrm{N}=13)$, prostaglandin $\mathrm{F} 2 \alpha(\mathrm{N}=17)$ or misoprostol $(\mathrm{N}=$ 19). Besides that, the authors did not use any kind of muscle relaxant or analgesic drugs which may have interfered in the results.

Regarding the order of passage our study suggests that repetitive manipulation of cervix interferes in transposition rate, as, in most of the animals, penetration was possible the third time they were used. Also, technician experience probably evolved with time. Regarding time of passage, all groups receiving hormonal treatments had higher rates of passage during the first attempt (10 minutes after epidural) and only control group had higher rates at 20 minutes, 
reflecting time where the epidural ketamine had its peak effect.

Considering analgesia, sedation, relaxation, total recumbency time, the association of epidural ketamine to oxytocin and estradiol after previous $d$-cloprostenol treatment was the most efficient protocol in dilating cervix in our study. Besides the facility of acquiring those hormones when comparing to misoprostol, i.v. injections are much more easily performed than the cervical administration.

\section{CONCLUSIONS}

Epidural injections of ketamine and its associations with xylazine and morphine in the doses proposed in this study were not capable of inducing cervical dilation in Santa Ines sheep. However, it was found that they promoted satisfactory analgesia and muscular relaxation. Ketamine alone promoted adequate analgesia without excessive time of recumbency or other undesirable side effects, being therefore considered the best choice for epidural administration. Oxytocin i.v. 12 hours after estradiol benzoate (also i.v.) in animals previously treated with $d$-cloprostenol was efficient in dilating the cervical canal in Santa Ines ewes allowing $90 \%$ of transposition rate and uterine flushing. The study established a pharmacological protocol that makes nonsurgical access to Santa Ines ewes' uteri feasible and ensuring animals well being.

\section{ACKNOWLEDGEMENTS}

This research was supported by Faperj, Universidade Federal Fluminense/Proppi/Fopesq, EMBRAPA (Project 02.03.06.026.00.02) and CNPq (400785/2016-1). JFF and FZB are CNPq fellows. JMGSF was supported by CAPES.

\section{REFERENCES}

ÁLVAREZ, M.; CHAMORRO, C.A.; KAABI, M. et al. Design and "in vivo" evaluation of two adapted catheters for intrauterine transcervical insemination in sheep. Anim. Reprod. Sci., v.131, p.153-159, 2012.
ARAÚJO, A.L.; SOUZA, G.A.F.; NÓBREGA NETO, P.I. et al. Tranquilização de asininos com acepromazina associada ou não ao diazepam. Arq. Bras. Med. Vet. Zootec., v.66, p.109-115, 2014.

CANDAPPA, I.B.; BARTLEWSKI, P.M. Induction of cervical dilation for transcervical embryo transfer in ewes. Reprod. Biol. Endocrinol., v.12, p.8, 2014.

DEROSSI, R.; CARNEIRO, R.P.B.; OSSUNA, M.R. et al. Sub-arachnoid ketamine administration combined with or without misoprostol/oxytocin to facilitate cervical dilation in ewes: a case study. Small Ruminant Res., v.83, p.74-78, 2009.

DEROSSI, R.; JUNQUEIRA, A.L.; LOPES, R.A. et al. Use of ketamine or lidocaine or in combination for subarachnoid analgesia in goats. Small Ruminant Res., v.59, p.95-101, 2005.

DEROSSI, R.; MÓDOLO, T.J.C.; PAGLIOSA, R.C. et al. Comparison of analgesic effects of caudal epidural $0.25 \%$ bupivacaine with bupivacaine plus morphine or bupivacaine plus ketamine for analgesia in conscious horses. $J$. Equine Vet. Sci., v.32, p.190-195, 2012.

DUQUE, M.J.C.; VALADÃO, C.A.A.; FARIAS, A. et al. Pre-emptive epidural ketamine or $\mathrm{S}(+)$-ketamine in post-incisional pain in dogs: a comparative study. Vet. Surg., v.33, p.361-367, 2004.

FALCHI, L.; SCARAMUZZI, R.J. An in vitro investigation of the actions of reproductive hormones on the cervix of the ewe in the follicular stage: the effects of 17 $\beta$-estradiol, oxytocin, FSH, and arachidonic acid on the cervical pathway for the synthesis of prostaglandin E2. Theriogenology, v.83, p.10071014, 2015.

FALCHI, L.; TAEMA, M.; LA CLANCHE, S. t al. The pattern of cervical penetration and the effect of topical treatment with prostaglandin and/or FSH and oxytocin on the depth of cervical penetration in the ewe during the peri-ovulatory period. Theriogenology, v.78, p.376-384, 2012.

FLOHR, S.F.; WULSTER-RADCLIFFE, M.C.; LEWIS, G.S. Technical note : development of a transcervical oocyte recovery procedure for sheep. J. Anim. Sci., v.77, p.2583-2586, 1999. 
FONSECA, J.F.; OLIVEIRA, M.E.F.; VIANA, J.H.M. Uso de procedimentos não cirúrgicos para a produção, recuperação e inovulação de embriões em pequenos ruminantes. Rev. Bras. Reprod. Anim., v.35, p.113-117, 2011.

FREITAS, G.C.; CARREGARO, A.B.; GEHRCKE, M.I.; DE LA CÔRTE, F.D.; LARA, V.M.; POZZOBON, R.; BRASS, K.E. Epidural analgesia with morphine or buprenorphine in ponies with lipopolysaccharide (LPS) - induced carpal synovitis. The Canadian J.Vet. Res. v. 75, p. 141-146, 2011.

GALATOS, A.D. Anesthesia and analgesia in sheep and goats. Vet. Clin. N. Am. Food Anim. Pract., v.27, p.47-59, 2011.

GREER, I.A.; MILLAR, M.; CALDER, A.A. Gemeprost-induced cervical ripening: histological and biophysical effects. Eur. J. Obstet. Gynecol. Reprod. Biol., v.47, p.1-9, 1992.

GUSMÃO, A.; SILVA, J.; QUINTELA, A. et al. Colheita transcervical de embriões ovinos da raça santa inês no semi-árido. Rev. Bras. Saúde Prod. Anim., v.8, p.1-10, 2007.

GUSMÃO, A.L.; SILVA, J.C.; BITTENCOURT, T.C.C. Coleta transcervical de embriões em ovinos da raça Dorper no semiárido do nordeste brasileiro. Arq. Bras. Med. Vet. Zootec., v.61, p.313-318, 2009.

KERSHAW, C.M.; KHALID, M.; MCGOWAN, M.R. et al. The anatomy of the sheep cervix and its influence on the transcervical passage of an inseminating pipette into the uterine lumen. Theriogenology, v.64, p.1225-1235, 2005.

KERSHAW, C.M.; SCARAMUZZI, R.J.; MCGOWAN, M.R. et al. The expression of prostaglandin endoperoxide synthase 2 messenger RNA and the proportion of smooth muscle and collagen in the sheep cervix during the estrous cycle. Biol. Reprod., v.76, p.124-129, 2007.
KERSHAW-YOUNG, C.M.; KHALID, M.; MCGOWAN, M.R. et al. The mRNA expression of prostaglandin E receptors EP2 and EP4 and the changes in glycosaminoglycans in the sheep cervix during the estrous cycle. Theriogenology, v.72, p.251-261, 2009.

LEME, M.C.; GONÇALVES, G.F.; INOE, A.P. et al. Avaliação do uso de Tiletamina e Zolazepam por via epidural em cães. Arq. Ciênc. Vet. Zool. UNIPAR, v.11, p.21-26, 2008.

MASOUDI, R.; KOHRAM, H.; SHAHNE, A.Z. et al. Effect of estradiol and oxytocin on ovine cervical relaxation. Afr. J. Biotechnol., v.11, p.2803-2806, 2012.

SANTOS, A.D.F.; SANTOS, D.C.; CONCEIÇÃO, J.C. et al. Taxa de gestação em fêmeas Santa Inês inseminadas pela via transcervical com sêmen fresco associada ou não à anestesia epidural. Rev. Bras. Saúde Prod. Anim., v.10, p.224-230, 2009.

SHAH, Z.; DING, M.X.; HU, M.L. Alfa2 antagonist in ruminant. Kafkas Univ. Vet. Fak. Derg., v.20, p.633-639, 2014.

STATISTICAL analysis system. Version 9.4. Cary: SAS Institute, 2012.

WULSTER-RADCLIFFE, M.C.; COSTINE, B.A.; LEWIS, G.S. Estradiol-17B-oxytocininduced cervical dilation in sheep: application to transcervical embryo transfer. J. Anim. Sci., v.77, p.2587-2593, 1999. 